\title{
Growing up in poor neighbourhoods
}

\author{
The significance of class and place in the \\ extended transitions of 'socially excluded' \\ young adults
}

Robert MacDonald, Tracy Shildrick, Colin Webster, and Donald Simpson

Youth Research Group

School of Social Sciences and Law

University of Teesside

Middlesbrough, TS1 3BA 


\title{
Growing up in poor neighbourhoods
}

\author{
The significance of class and place in the extended transitions of \\ 'socially excluded' young adults
}

\begin{abstract}
Drawing upon qualitative, longitudinal research with 'socially excluded' young adults from some of England's poorest neighbourhoods, the paper explores how locallyembedded, social networks become part of the process whereby poverty and class inequalities are reproduced. Networks of family and friends, rooted in severely deindustrialised locales, supported young people as they carved out transitions to adulthood in adverse circumstances. Examples are given in respect of informants' highly localised housing careers and their longer-term experience of 'poor work'.

Paradoxically, though, whilst local networks helped in coping with the problems of growing up in poor neighbourhoods and generated a sense of inclusion, the sort of social capital embedded in them served simultaneously to close down opportunities and to limit the possibilities of escaping the conditions of social exclusion. Overall, and contrary to some recent youth sociology, the paper stresses the continuing importance of class and place in shaping youth transitions.
\end{abstract}

Key words: class, neighbourhood, place, social exclusion, young adults. 


\section{INTRODUCTION}

This is a paper about the longer-term transitions of young people from some of the poorest neighbourhoods in England ${ }^{1}$. Through longitudinal, qualitative research with so-called 'hard-to-reach' young adults, it offers an insight into contradictory, lived experiences of 'social exclusion' and 'inclusion' (Levitas, 1998; Hills et al, 2002). In terms of broader, class theory, our case-study approach follows in that vein of ethnographic research and critique (e.g. Skeggs, 1997; Charlesworth, 2000; Reay, 2003) that seeks to understand, 'from below', how social actors subjectively perceive (or sometimes fail to see) the unequal conditions of class and place that frame their biographies. A case-study approach is also useful for studying dynamic class

processes (Morris, 1996; Crompton, 1998; Crompton et al, 2000) ${ }^{2}$ and a focus on the youth phase provides a valuable vantage point from which to study how class categories are reformed, re-populated and/ or re-configured.

The paper has four parts. The first describes our research projects. The second examines young adults' experiences and feelings in respect of their impoverished neighbourhoods. The third part of the paper sketches out typical patterns of labour market engagement, focusing on the search for work. The fourth considers the role of networks in generating subjective, paradoxical experiences of social inclusion. In conclusion, we discuss the consequences of these forms of social network and place attachment for young adults' class trajectories.

\section{RESEARCHING EXTENDED YOUTH TRANSITIONS AND SOCIAL EXCLUSION: A CRITICAL}

\section{CASE STUDY}

The value of the concept of transition has been hotly contested in youth sociology. Because the movement to adulthood now tends to be marked by unpredictability, backward steps and false starts (Du Bois-Reymond, 1998; EGRIS, 2001) - and because the youth phase has become more fragmented and extended (Cohen and Ainley, 2000) - several writers have distanced themselves from structurally-oriented, 
class-based analyses of youth transitions in favour of theories about individualisation and the Risk Society (Giddens, 1990, 1991; Beck 1992). Cieslik and Pollock (2002:3) summarise the argument as follows:

In the place of these collective guides and traditional institutions are much more individualized identities and biographies where individuals have a greater scope beyond traditional markers of class, race and gender to create complex subjectivities and lifestyles.

We give a fuller response to critics of transition studies elsewhere (MacDonald et al, 2001). In brief, we accept many of their separate, empirical points about how, since the 1970s, youth transitions have become more complicated, extended and apparently less class-bound. This does not, however, invalidate the concept of transition. Following Furlong and Cartmel (1997), we argue that opportunities in youth and final destinations in adulthood are still strongly influenced by an individual's original location in the class structure, despite the fact that the risks and uncertainties of restructured transitions tend to engender a greater sense of individual autonomy. For instance, summarising much recent youth research and drawing upon the alternative terminology of 'social exclusion', Jones (2002) stresses the hardening up of 'the youth divide'. Those (typically working-class young people) that make the speediest transitions into the labour market, to parenthood and to independent living, face greater risks of the negative outcomes associated with social exclusion.

In the same vein, we argue that - because the youth phase is so critical to social reproduction - a qualitative, longitudinal perspective on processes of transition to adulthood remains vital to understanding how familiar social class, gender and ethnic divisions are re-populated, contested or overcome. Miles (2000: 10) argues that 'the most damaging problem' with transitions studies is that they have 'tended to take young people out of the youth equation'. Although he forgets much research that does prioritise young people's own accounts of transition, Miles is correct to stress the active role of young people in these processes. In drawing upon the sociological concept of 'career' (Becker, 1963; Berger and Berger, 1972), we explore the way that individual decision-making, informed by young people's cultures and sub-cultures, 
interacts with socially structured opportunities to create individual, and shared, paths of transition.

Also correct is the criticism that transition studies have tended to focus on 'school-towork careers' (the move from full-time education into the labour market) to the detriment of wider aspects of youth experience (Cohen and Ainley, 2000). Coles (1995) broadens the scope of transition studies to include as well 'family careers' (the attainment of relative independence from family of origin) and 'housing careers' (the move away from the parental home). On the basis of our earlier studies (Johnston et al, 2000), we suggest that 'criminal careers', 'drug-using careers' and 'leisure careers' can also become important in shaping youth transitions (these terms are explained in MacDonald and Marsh, 2005). These six 'careers' became the focus of our interviews with young people.

\section{The Teesside studies}

This paper is based on three, related studies. The first two of these (Johnston et al, 2000 and MacDonald and Marsh, 2001, 2002, 2005), shared an interest in how 15 to 25 year olds from the 'Willowdene' and 'East Kelby' neighbourhoods of 'Kelby', Teesside evolved transitions to adulthood. In the late 1990s, the seven wards that comprise these neighbourhoods all featured in the top five per cent most deprived nationally (DETR, 2000) and two of them ('Orchard Bank' and 'Primrose Vale') were in the worst five - of 8,414 - in England. Both studies involved periods of participant observation and interviews with professionals who worked with young people. At their core, though, these studies relied on lengthy, tape-recorded, biographical interviews (Chamberlayne et al, 2002) with 186 young people (82 females and 104 males) from the predominantly white, (ex)manual working-class population resident in 'one of the most de-industrialised locales in the UK' (Byrne, 1999: 93).

There is not the room here to review these studies' findings. We note only that whereas at the level of the individual case, informants described differentiated family, housing, leisure, criminal and drug careers, they were united by a common experience of economic marginality. The majority displayed highly conventional attitudes to 
employment but their late teenage school-to-work careers struggled to progress beyond low paid, low skill, insecure 'poor work' (Brown and Scase, 1991).

Our most recent study (Webster et al, 2004), carried out in 2003, was designed as a follow-up to these two, earlier ones. The key research question was where such transitions led individuals in their mid to late twenties? Were people eventually able to carve out more progressive transitions, even in unpromising circumstances? Or were longer-term problems of poverty and social exclusion cemented in place by early experiences of economic marginality?

We re-interviewed 34 people (18 females and 16 males), now aged 23 to 29 years, from the two original samples. We sampled theoretically so as to understand, in particular, the longer-term transitions of: young women who, at last interview, had been committed to full-time parenting (n. 11); young people who had displayed enduring but unrewarding efforts to engage with education, training and employment (n. 11); and of individuals who previously had serious involvement in criminal and/ or drug-using careers (n. 12).

No claim can be made that these 34 individuals are strictly representative of the larger samples of the first studies. That said, through dogged fieldwork (e.g. repeated visits and 'phone calls to home addresses, checking of the electoral register to seek the new addresses of those that might have moved) we were able to locate the whereabouts of the majority of those from the earlier studies that were now aged 23 to 29 years. Through re-reading original interview transcripts, we selected from these those that best exemplified the sort of transitions that we were now particularly interested in. As we describe shortly, individuals remained tied to locally-rooted, social networks. This meant that interviewees in the early phase of the follow-up study could often help us find friends or acquaintances of theirs that we wanted to re-contact. Whilst not a perfect method, the brief cameos of potential re-interviewees gathered from actual interviewees make us think that the sample for the follow-up study is generally representative of the initial, larger samples. 
In this paper we draw upon all three projects. In doing so, we present research that is relatively unusual in contemporary British social science. Not only are the nearly two hundred young adult participants often described as 'hard to reach' (Merton, 1998), this longitudinal, qualitative research provides for a rare, close-up insight into they ways those people at the sharp end live in - and through - the conditions of social exclusion.

\section{LIVING IN POOR NEIGHBOURHOODS}

\section{Localised housing careers}

The most striking finding about these people's housing careers was their localisation. The original, ESRC study attempted two interviews with its participants, separated by about year. Whilst we discovered much 'local nomadism' (i.e. people moving address within East Kelby), only one interviewee left the town during that fieldwork (two young men had also moved away in very short-lived, ill-fated attempts to seek employment).The follow-up study was able to locate only one, further person from our original studies who had left the area. By their mid to late twenties, to the best of our knowledge, virtually all interviewees remained living in the neighbourhoods in which they had been born and brought up ${ }^{3}$.

This is partly a result of the local housing market. Ford et al's more general survey of youth housing careers (2002) found that the private rented sector often underpinned 'unplanned' and 'chaotic' housing pathways. Whilst these were typical of many in our studies, only a few people had ever had private tenancies. Even single, young men one of the least needy social groups according to local authority housing policy - had been offered council bed-sits. The availability of social housing in these neighbourhoods, compared with other urban areas (Social Exclusion Unit, 1999), helps explain the high frequency of moving we uncovered and why apparently nomadic housing careers were locally circumscribed. As with school-to-work careers, we cannot theorise housing careers only by reference to the local structure of opportunities. Many informants, probably the majority, preferred to remain in wards that suffered from extreme problems of social exclusion. How do we explain this? 


\section{Knowing and being known: the importance of family and social networks}

The most important answer relates to the embeddedness of these individuals in close, locally-concentrated family and social networks. Consider Carol-Anne's answer, aged 24 at the time of our first studies, to a question about living in Primrose Vale, a ward rated in the top five most deprived in England:

I like it. It's good. It depends which part you live in. Where we live, it's quite quiet. All our family live dead close together ...//...I've got a cousin lives at number 2. One lives at number 9, one 16. We live at 26 and my Auntie lives at 30. All in the same road, and then, like, I've got two cousins that live round the corner and then a cousin that lives in Orchard Bank...//... they're always there if you need 'em. You're just dead close and good but the bad thing is, like, they all know what's going on! [laughing].

Carol-Anne was the only interviewee to move away from Kelby during the original fieldwork. At 27, as part of our follow-up study, she remarked that 'leaving home was the best thing and the worst thing I've ever done', explaining the negative aspects of this in terms of her separation from family. Young women (lone mothers in particular) explained their desire to stay nearby to their families of origin for emotional and practical reasons (e.g. because of the informal support offered in terms of childcare and the support they gave to parents).

Being rooted in social networks that extended beyond family also emerged as important in positive evaluations of these places. At the age of 20, when we first interviewed him, Martin gave one of the most up-beat assessments of community life in Primrose Vale: 
Martin: Living here, it's brilliant. We have no problems with anyone. We know all the thugs and the thieves and whatever but everyone's okay...It's a lot better if you know someone and something goes wrong. If you have problems, you can always call on people. They're always quite loyal in that sense.

JM: Do you think there's a great community spirit?

Martin: It depends on what you call community spirit. It's really an underground kind of thing. It's the backing...//...everyone supports you. Neighbours come over and they wanna borrow money until they get paid, things like that. You know you'll get it back, so...You can always rely on everyone else. If you're stuck, someone'll help you.

We would not wish to romanticise everyday life in these neighbourhoods. Martin, too, was notably cautious about our suggested term 'community spirit'. He interlaced his positive commentary on East Kelby with, albeit passing acknowledgement of the problems of living here (e.g. of thieving, thuggery, poverty). Virtually all interviewees recognised the same difficulties. They were particularly vociferous in their condemnation of the local effects of heroin dealing and use, and associated criminal victimisation (such as house burglary) (MacDonald and Marsh, 2002). Allan (21), whose family home had been burgled ten times, said:

... these council estates, phwoah! It's a hard graft growing up in these, you know? It's full of TWOCs ['taking cars without the owner's consent'] and it's just the heroin that does my head in. Seeing people rotting away on it. It's a disgusting drug, that.

Yet, once or twice, interviewees hinted at the idea that less troubled places might experience less of a sense of social inclusion and support. They wondered whether the hardships they collectively endured encouraged informal ways of coping which, in turn, generated a stronger sense of attachment to the place (Kearns and Parkinson, 2001). Broderick, aged 18 at first interview, implies this in the following comment: 
Like you've gotta watch your back everywhere you go...//... when they leave the house, they'll walk past and say, 'Here, Broderick, you're round the area, just watch our house while I'm out'. I'll say 'Alright' and then I'll just keep an eye on their house.

Zack (23), Martin's friend, was an unusual case in that he often visited other parts of the country. He captured the ambivalence implied in many accounts of life on these estates and underlined Martin's statement that knowing and being respected by criminal networks was influential in experiencing life here as live-able ${ }^{4}$ :

Every time I come back to Primrose Vale - as soon as I see the A66 - I know I'm home. I feel dead relaxed, as if it's a weight off your shoulders...//...I don't like the place!...//...You're secure. It's a security blanket; the place where you were raised...//...Every area is different. Areas with loads of money, you're respected 'cos who your family are and what money you've got. Round here, it's if you're hard as fuck [tough/ violent]. Or if you're a drug dealer, you're respected. If you do things within the community, you're respected...//...A lot of people do [want to move away from Primrose Vale] people who aren't involved in the circles of knowing people; knowing the people. There is hard people in every estate...You have to know the big people, do you know what I mean? And you have to know the kids that are knocking about on the street.

Some interviewees were obviously better connected to criminal networks than others. Broderick had been a small-time player himself and Zack referred, with a nod and a wink, to his contacts in drug supply chains. Others, like Martin, had had virtually no criminal involvement but, with Zack, was well known in Primrose Vale for his informal, untrained youth work on the estate (MacDonald and Marsh, 2001). Several interviewees insisted that there was practical value in possessing a personal or family reputation that was respected in the circles that maintained sometimes violent, informal social control on these estates (circles that overlapped with those engaged in particular forms of crime). Informal surveillance of each others' houses (as a deterrent against burglary), the return of stolen possessions following burglaries and the settling of personal or family feuds by 'hard' intermediaries were all given as examples. One 
youth worker said he knew of streets in East Kelby where 'one lad would do your leccy [fix the electricity meter so that bills were reduced] and another would bring round [stolen] kids' clothes for you. It's just a way of getting by'.

\section{The normalcy of social exclusion}

Regardless of whether the majority who made appreciative remarks about their home locales were as accepted by/ accepting of local criminals, drug dealers and street gangs as Zack suggests, familiarity with these places was key to understanding why most wished to stay (Atkinson and Kintrea, 2004) ${ }^{5}$. Even people like Ellie (26), who were less happy about living in Primrose Vale, became accustomed to the signs of social decline:

...you can see glue bags and needles, but that's just something else which has become sort of everyday...going for a walk with the dog past a burnt out car and it's the most normal thing in the world to see...//...something that sounds like a car backfiring could just as easily be somebody shot.

To re-iterate, most had lived here permanently and had very limited lived experience of places beyond Kelby. They had little to compare it against. They did not really know how their contemporaries in more prosperous locales fared and without a more global vantage point it was difficult for them to perceive in full the spatial polarisation of class inequality. Partly because they were so familiar with their own (geographic) place, they had strikingly little awareness of their subordinate place in wider class structures ${ }^{6}$. When presented with this sort of information, as when the local newspaper reported Primrose Vale's pole position in 'the geography of misery' (Burrows and Rhodes, 1998), its accuracy was denied: 'it was in the news. I don't think it's true. I don't think it's as bad as that. I think there's worse places' (Elizabeth, 19).

Designation, and self-designation, of the 'excluded' necessitates reference to the 'included' (Sibley, 1995). None recognised the term 'social exclusion' and only a handful felt that it described their lives, once it was explained. All by the fact of their residence confronted the objective problems of social exclusion (i.e. of growing up in 
a poor, high crime, high unemployment locality). Few felt, however, that the problems they did experience were particularly unusual or noteworthy. Why we, as researchers, should be interested in them was a not uncommon question.

Perhaps because Kelby has the highest concentration of deprived wards of any town in the country, interviewees were able to reel off the names of other neighbourhoods that they imagined to be 'worse' than their own and only a few ever referred to more affluent wards - 'quieter' places with 'nicer houses' where people were 'posher' (Mally). This lack of contrast underpinned their bemusement at the idea that they might somehow be different (i.e. 'socially excluded') and was further reinforced by the narrowing down and closing in on the immediate neighbourhood of individuals' social networks as the years passed; a phenomenon reported by all in our follow-up study. Opportunities for comparison with more 'successful' or affluent biographies were never great, but virtually disappeared as interviewees reached their midtwenties. By this point, those around them were just like them. Informants reported circles of friends comprised of others in very similar circumstances. Young mothers tended to socialise with other young mothers. Those immersed in long-term criminal or drug-using careers associated with people on a similar track. The recurrently unemployed had friends who were in the same boat.

Together this (largely) unquestioned acceptance of the normalcy of their experiences of growing up in poor neighbourhoods, their familiarity with the place and their inclusion in strong, supportive family and social networks meant that most saw no reason to leave Willowdene or East Kelby.

\section{LIFE AT THE BOTTOM OF THE LABOUR MARKET}

\section{Cyclical careers and 'poor work'}

Typical of youth transitions in these places at this time, the vast majority of our interviewees left school at 16 with low or no educational qualifications for 'cyclical' school-to-work careers (Craine, 1997). That is, virtually all displayed work histories into their mid and late twenties - that consisted of various combinations of: government schemes that rarely led to lasting employment; unfinished and/ or low- 
level educational courses; low/ no skill, low paid, insecure employment; and recurrent periods of unemployment. Individuals transited between these labour market statuses with little sense of forward motion toward more secure, rewarding employment. Furlong and Cartmel's (2004: 27) study of the longer-term fortunes of disadvantaged young men in Scotland reports findings that are virtually identical to ours:

...their main problem was not finding work, but keeping it. This employment insecurity tended not to reflect negative attitudes on the part of the young men or necessarily a lack of skills; it was almost entirely a consequence of the 'flexible' nature of low-skilled employment in modern Britain

The sort of jobs our informants got - in the lower reaches of the service industries and routinised, factory production - were not confined to school leavers. There was little indication that people worked their way through them before accessing higher positions. They were the jobs that individuals laboured at when they were seventeen and when they were twenty-seven. These were also the sort of jobs their parents now did, when they worked. Many of our interviewees reported that, even if their fathers (and some mothers) had previously enjoyed Fordist forms of standard employment in traditional industries, they were now similarly economically marginal: working on short-term contracts, in under-skilled jobs, unemployed, 'retired', 'on the sick' or otherwise economically inactive ${ }^{7}$. In this context, getting a job that paid $£ 4.50$, rather than $£ 3.50$ an hour, was counted as a good outcome and potential jobs in call centres or as bus drivers were regarded as a step up. They did 'poor work' (Brown and Scase, 1991), often for seemingly punitive employers who, according to these accounts, were as quick to fire as they were to hire willing workers ${ }^{8}$.

We are not, then, describing the details of a separate youth labour market (Ashton and Maguire, 1986) but a secondary labour market (Beynon, 1997), marked by pervasive unemployment and underemployment, to which many working-class people younger and older alike - are now confined: 
Low pay is also fair enough if these jobs can be labelled 'entry-level', just a first step on a ladder. But it is now clear that very few of those in low-paid jobs can ever move far...//... few make it to the next step. They inhabit a cycle of no-pay/ low-pay job insecurity. This indeed is the end of social progress.

Toynbee (2003: 5-6).

Byrne suggests that 'what is absolutely missing' from many accounts of the socially excluded is 'the significance of the combination of low wages, insecure employment and dependence on means tested benefits...//...poor work is the big story' (1999: 69). His argument is that the need of post-industrial capitalism for a 'flexible', reserve army of labour means that low-paid work punctuated by unemployment 'represents the most significant kind of excluded life in our sort of society' (74). We do not have the room here to appraise critically Byrne's theoretical position (for instance, the extent to which this sort of 'poor work' is an inevitable, ever-present outcome of contemporary capitalism) but we do note its resonance with the details of our empirical studies. We conclude that unemployment, job insecurity and poor work have become common working-class experiences, rather than the preserve of a wholly excluded underclass positioned beneath them.

That the majority of young adults stuck with this sort of working life - moving in and out of casualised employment over the post-school years - is evidence of their negative assessment of other possibilities (Youth Training (YT), New Deal for Young People (NDYP), further education), the dearth of more rewarding jobs for the underqualified and what we describe as a hyper-conventional attitude to work in which the getting of work, even 'poor work', was the driving force behind most youth transitions. Murad found this same class-based 'work ethic and enthusiasm for work' amongst excluded groups in continental Europe, describing its 'persistence in current times' as 'remarkable' (2002: 98). 


\section{Searching for jobs}

We have described interviewees' school-to-work careers in general terms. But how did young adults access employment in neighbourhoods of persistent joblessness?

Overwhelmingly, interviewees found informal job-search strategies to be most effective (Marsden and Duff, 1975; Morris, 1995). Personal networks for information, advice and recommendation were crucial in getting work. Knowing others who worked, or had worked, in a particular firm gave access to information about vacancies and allowed for personal recommendations by these intermediaries. Friends, neighbours and family members were mentioned as the key players that helped secure jobs and, on a rough count, over two-thirds of all jobs had been got in this way:

There's this part-time job at the turkey factory. They're looking for people. I've asked this lad - cos his uncle works there - to see if they want any more.

Lindsay (17, YT trainee).

My Dad said 'tell Louise - that's my girlfriend - to give us the number of her gaffer'. So he rang him and he said 'oh, you [Malcolm] can start so and so a time'.

Malcolm (21, NDYP participant).

In comparison, the methods encouraged by Job Centres, Job Clubs and the NDYP were seen as wholly ineffective. These include the sending of speculative application letters to local employers, regardless of whether they were currently advertising vacancies or not. Eligibility for 'Job Seekers Allowance' (the main unemployment benefit for this age group) requires recurrent evidence of such applications. By the time informants entered the job-search sessions on NDYP they had usually encountered this strategy several times before on other programmes. Because their CVs and standard application letters were by now as polished as they were ever going to be - and because they (and perhaps tutors) recognised this strategy to be 
ineffectual - participants were 'just left in the canteen all day' (Allan, 21) or asked 'to sit looking through the papers and there's no way you can do that for three hours, so we end up just sitting there bored' (Elizabeth, 19). This 'totally stupid' strategy rarely received any response. Not one interviewee reported receiving a job offer as a result, despite them having fired off, collectively, several thousand letters. Even rejection letters were rare, but when received pointed to what these young hopefuls lacked: no references from previous jobs, inadequate qualifications, slim work experience, no driving licence, too young, too old, etc.

Adam (21) was just one of those frustrated by the lack of opportunity to prove his worth: 'it's just what's on that piece of paper [the application form] and they look at it and they say “do we want him or don't we want him?" That piece of paper holds me back'. The 'future blocking' potential of the CV was most pronounced for those with criminal records, who stood towards the back of the job queue. Consequently, fake work histories had to be concocted: 'that's how I've got most of me jobs, through lying' (Richard, 20). For some, this pattern of 'sending stuff all the time and not hearing' (Leo, 22) and occasional outright rejection became a demotivating series of personal knock-backs.

\section{SOCIAL INCLUSION AND SOCIAL CAPITAL: THE PARADOX OF NETWORKS}

Measures of inclusion/ exclusion often refer to social as well as economic participation (e.g. involvement in community life, the level of social support available) (Hills et al, 2002). On these scores, it would be difficult to categorise our interviewees as excluded. Many felt included. Most informants were connected to the life of their estates in ways untypical of residents of those apparent paradigms of social inclusion and order: middle-class, suburban neighbourhoods (Baumgartner, 1988). Although it is fashionable to explain neighbourhood decline in terms of the lack of social cohesion, community spirit and social capital (e.g. Etzioni, 1993; Putnam, 1995), the majority here did not seem short of strong, close, supportive relationships. Forrest and Kearns claim that (2001: 2141) 'close family ties, mutual aid and voluntarism are often strong features of poor areas' and help people 'cope with poverty, unemployment and wider processes of social exclusion'. 
This was certainly true of our study and we have picked out just two empirical examples from many of the influence on youth transitions of informal, social networks of family, kin and friends. They helped explain the localisation of housing careers and the positive way that young adults described what are, by any measure, poor locales. In searching for jobs, informants relied on 'who they knew, not what they knew' and got most of the employment they had ever had via tip-offs and recommendations provided by networks of family and friends.

As Perri 6 notes, however, 'we must not celebrate...//... any kind of network or any kind of social capital...//...some networks may be very damaging for everyone else and perhaps, in the longer-term, for themselves' (1997: 21). Involvement in criminal networks was the example of 'destructive social capital' he was referring to here. In our studies, too, prolonged immersion in street-based, youth cultural identities was crucial in entrapping some participants in criminality and dependent drug use. Desistence depended upon separation from such networks (Webster et al, 2004).

Talking of social exclusion in Southern Italy, Spano says that: 'networks based on kinship as well as on friendship can easily become a constraint...//...by enclosing the subject in a limited social space, they can preclude [the] possibility of having new opportunities, of working out new projects, of maturing new aspirations' (2002: 73). To use Putnam's phrase (2000: 23, cited in Kearns and Parkinson, 2001): 'bonding social capital bolsters our narrower selves'. Perhaps the clearest example of the potentially malign influence of social networks is that usually presented by informants as one of their main benefits.

\section{The weakness of strong ties}

Reviewing Granovetter's (1973) and more recent studies of networks, Perri 6 (1997: 10-11) concludes that, compared to the middle-class, working-class people are more likely to suffer from 'network poverty': a paucity of weak ties to more extensive, socially diverse networks 'that are more useful in advancing oneself in the labour market' and transcending the limiting socio-economic conditions in which they live. W.J. Wilson reports the same in respect of the American ghetto poor (1996: 65). Kearns and Parkinson sum it up neatly: 'the neighbourhood for poorer people has 
more often served as an arena for "bonding" social capital that enables people to "get by', rather than as a platform for "bridging" social capital that enables people to 'get on' (2001: 2105).

One practical consequence of our informants' strong ties to neighbourhood-based networks was that job search became proximate with the spatial reach of such networks: 'the value of informal networks militates against mobility. Networks, whether based on the family or friends, depend on people's roots in a locality: they take time to establish' (Kelvin and Jarrett, 1985: 30). There is a double-bind here. Attachment to place was partly explained in terms of the aid local networks gave in finding employment but commitment to them militated against moving to where jobs might be more easily found. Moving would isolate individuals from networks and practices they knew to be effective in getting work: 'you're, like, friendly with everybody round the area and when you go away it'll take time, won't it?' (Broderick).

Immersion in local social networks impacted not only upon the geographic range of job search. Because those that helped in finding jobs were also typically confined to the same sectors of the labour market as them, our interviewees remained constrained to work at the bottom of the labour market that offered little chance of personal progression. Interviewees became trapped in insecure, 'poor work' with little or no training or prospect of internal promotion and few bridges to more permanent, rewarding employment and, thus, were unable to escape the churning of cyclical labour market careers (White and Forth, 1998; Strathdee, 2001). As the years passed, they became even less attractive to those with better employment to offer (Furlong and Cartmel, 2004).

So, paradoxically, whilst connections to local networks could help in coping with the problems of growing up in poor neighbourhoods and generate a sense of inclusion, the sort of social capital embedded in them served simultaneously to limit the possibilities of escaping the conditions of social exclusion. 


\section{CONCLUSION}

We do not, conclude, however, that the poverty and economic marginality experienced by our research participants is a direct product of their social networks and cultural practices. For us, the rapid, widespread de-industrialisation of Teesside a place that was, until relatively recently, one that 'worked' - is central to any understanding of the contemporary, extended transitions of its young adults (Beynon et al, 1994; Byrne, 1999). What we see in our interviewees' biographical accounts is their various, resourceful, resilient ways to negotiate the wreckage of the collapsed 'economic scaffolding' that previously enabled transitions to a stable, working-class, adult life (Salo, 2003). In this context, supportive social networks proved indispensable.

We interpret the forms of neighbourhood-based sociality and mutuality described by our interviewees as aspects of their class cultural inheritance. After all, the significance of our finding about the localisation and embeddedness of their housing careers comes not from its novelty - many, earlier studies of working-class community revealed a similar, stable pattern of cultural life rooted in place (Jackson, 1968; Roberts, 1978) - but from the fact, firstly, that there is a trend in contemporary youth theory that explicitly denies the continuing influence of (working) class culture on youth transitions and, secondly, that the economic basis of local, working-class life has so radically altered. Similarly, the contemporary, informal job-search strategies of these young adults are clear echoes of those found amongst the young working-class thirty to forty years ago (Carter, 1962; Ashton and Field, 1976).

Overall, then, our findings stand against those that declare 'the death of social class' (Pakulski and Waters, 1996) in post-modern times and 'the disappearance of the local under global processes' (Brewer, 2000: 173). We, like Brewer, argue that ethnography can reveal the continuing sociological relevance of class and place in understanding lived experience. This still holds true even if, because of their sense of the everyday, widespread normalcy of 'social exclusion', the subjects of this discussion largely failed to appreciate how their collective biographies had been shaped in particular ways by being working-class, young and from Teesside's poor neighbourhoods ${ }^{9}$. 
In a context of 'structured individualisation' (Roberts, 1997: 59) ${ }^{10}$, young people may well regard themselves as free agents making their own, individual ways in the world (as our interviewees tended to do) but continue to derive from their family, class backgrounds particular sorts of social and cultural capital rooted in local economic history and conditions (Forrest and Kearns, 2001). And whilst global capital might only perceive Teesside as 'a (temporary) space for profitable production', this is also a place where people have:

...networks of friends, relatives and acquaintances, where they have learned about life and acquired a cultural frame of reference through which to interpret the social world around them...//...As a result, people have often become profoundly attached to particular places, which come to have socially endowed and shared meanings which touch on all aspects of their lives, helping shape who they are by virtue of where they are.

Beynon et al (1994:5).

Like Atkinson and Kintrea (2004: 452), we are wary of replicating victim-blaming, underclass theories but acknowledge that 'cultural factors' can be 'part of the explanation for the persistence of poverty'. The class-based values, identities and social practices evinced in young adults' valorisation of community life and the social networks embedded therein, do now play a role in entrenching the unequal life chances that befall the young residents of Willowdene and East Kelby. The getting of jobs relied on forms of social capital and social practice that once enabled, for men at least, the transition to relatively lasting, 'proper jobs'. Relying on tip-offs and personal recommendations in searching for employment now leads, instead, to 'poor work' in the turkey factory. As such, our informants have been dispossessed even of the opportunity to make the sort of secure, 'respectable', working-class life known by their grandparents, let alone the chance of limited social progress up and away from the working-class condition that was previously possible for some (Toynbee, 2003). In this context, practices that once helped working-class young adults 'get on' now, at best, only help them to 'get by'. 


\section{References}

Ashton, D., and Field, D. (1976) Young Workers, London: Hutchinson.

Ashton, D., and Maguire, M. (1986) Young Adults in the Labour Market, Research Paper 55, London: Department of Employment.

Atkinson, R., and Kintrea, K. (2004) 'Opportunities and despair: it's all in there', in Sociology, 38, 3: 437-455.

Ball, S., Maguire, M. and Macrae, S. (2000) Choice, Pathways and Transitions Post16, London: Routledge/ Falmer.

Baumgartner, M. (1998) The Moral Order of the Suburb, New York: Oxford University Press.

Beck, U. (1992) Risk Society, London, Sage.

Becker, H. (1963) Outsiders, Glencoe, Free Press.

Berger, P., and Berger, B. (1972) Sociology: A Biographical Approach, New York, Basic Books.

Beynon, H. (1997) 'The Changing Practices of Work', in Brown, R.K. (ed) The Changing Shape of Work, Basingstoke: Macmillan.

Beynon, H., Hudson, R., and Sadler, D. (1994) A Place Called Teesside, Edinburgh University Press: Edinburgh.

Brewer, J. (2000) Ethnography, Milton Keynes: Open University Press.

Brown, P. and Scase, R. (eds.) (1991) Poor Work, Milton Keynes, Open University Press. 
Burrows, R. and Rhodes, D. (1998) Unpopular Places?, Bristol: The Policy Press.

Byrne, D. (1999) Social Exclusion, Milton Keynes: Open University Press.

Carter, M. P. (1962) Home, School and Work, London: Pergamon.

Cieslik, M., and Pollock, G. (2002) 'Introduction', in Cieslik, M., and Pollock, G. (eds.) Young People in Risk Society, Aldershot: Ashgate.

Chamberlayne, P., Rustin, M., and Wengraf, T. (eds.) (2002) Biography and Social Exclusion in Europe, Bristol: Policy Press.

Charlesworth, S. (2000) A Phenomenology of Working Class Experience, Cambridge: Cambridge University Press.

Cohen, P., and Ainley, P. (2000) 'In the country of the blind? Youth studies and cultural studies in Britain', Journal of Youth Studies, 3, 1: 79-95.

Coles, B. (1995) Youth and Social Policy, London: UCL Press.

Craine, S. (1997) 'The Black Magic Roundabout', in MacDonald, R. (ed.) Youth, the 'Underclass' and Social Exclusion, London: Routledge.

Crompton, R. (1996) 'The fragmentation of class analysis', British Journal of Sociology, 47: 56--67.

--- (1998) Class and Stratification, Cambridge: Polity Press (2nd edition).

Crompton, R., Devine, F., Savage, M., and Scott, J. (2000) Renewing Class Analysis, Oxford: Blackwells.

DETR (2000) Index of Multiple Deprivation, London: Department of the Environment, Transport and the Regions. 
Du Bois-Reymond, M. (1998) “'I don't want to commit myself yet': young people's life concepts", Journal of Youth Studies, 1, 1: 63-80.

EGRIS (European Group for Integrated Social Research) (2001) 'Misleading trajectories: transition dilemmas of young adults', in Journal of Youth Studies, 4, 1: 101-118.

Etzioni, A. (1993) The Spirit of American Community, London: Simon and Schuster.

Ford, J., Burrows, R., and Rugg, J., (2002) Young People, Housing and the Transition to Adult Life, ESRC Youth, Citizenship and Social Change Research Briefing, 1.

Forrest, R. and Kearns A. (2001) 'Social cohesion, social capital and the neighbourhood', Urban Studies, 38, 12: 2125-2143.

Furlong, A. and Cartmel, F. (1997) Young People and Social Change, London: Open University Press.

--- (2004) Vulnerable Young Men in Fragile Labour Markets, York: Joseph Rowntree Foundation.

Giddens, A. (1990) The Consequences of Modernity, Cambridge: Polity Press.

--- (1991) Modernity and Self-identity Cambridge: Polity Press.

Granovetter, M. (1973) 'The strength of weak ties', American Journal of Sociology, 78: $1360-1380$.

Hills, J., Le Grand, J., and Piachaud, D. (eds.) (2002) Understanding Social Exclusion, Oxford: Oxford University Press.

Jackson, B. (1968) Working Class Community, London: RKP. 
Johnston, L., MacDonald, R., Mason, P., Ridley, L. and Webster, C., (2000) $\underline{\text { Snakes }}$ $\underline{\text { \& Ladders, Bristol: Policy Press }}$

Jones, G. (2002) The Youth Divide, York: Joseph Rowntree Foundation/ York Publishing Services.

Kearns, A., and Parkinson, M. (2001) 'The Significance of Neighbourhood' Urban Studies, 38, 12: 2103-2110.

Kelvin, P. and Jarrett, J. (1985) Unemployment: Its Social Psychological Effects, Cambridge: Cambridge University Press.

Levitas, R. (1998) The Inclusive Society?, Basingstoke: Macmillan.

MacDonald, R., and Marsh, J. (2001) 'Disconnected Youth?', in Journal of Youth Studies, 4, 4: 373-391.

--- (2002) 'Crossing the Rubicon: Youth Transitions, Poverty Drugs and Social Exclusion', in International Journal of Drug Policy, 13: 27-38.

--- (2005) Disconnected Youth? Growing up in Poor Britain, Basingstoke: Palgrave.

MacDonald, R., Mason, P., Shildrick, T, Webster, C., Johnston, L., and Ridley, L. (2001) 'Snakes and Ladders: In Defence of Studies of Transition', Sociological Research On-line, 5, 4.

Marsden, D., and Duff, E. (1975) Workless, Harmondsworth: Pelican.

Merton, B.(1998) Finding the Missing, Leicester: Youth Work Press.

Miles, S. (2000) Youth Lifestyles in a Changing World, Buckingham, Open University Press. 
Morris, L. (1995) Social Divisions, London: UCL Press.

--- (1996) 'Classes, underclasses and the labour market', in Lee, D., and Turner, B. (eds.) Conflicts About Class: Debating Inequality in Late Industrialism, London: Longman.

Murad, N. (2002) 'The shortest way out of work', in Chamberlayne, P., Rustin, M., and Wengraf, T. op. cit.

Pakulski, J. and Waters, M. (1996) The Death of Social Class, London: Sage.

Perri 6, (1997) Escaping Poverty: From Safety Nets to Networks of Opportunity, London: Demos.

Putnam, D. (1995) 'Bowling Alone: America's declining social capital', Journal of Democracy, 6, 1: 65-78.

Reay, D. (2003) 'Class, authenticity and the transition to higher education for mature students', The Sociological Review, 50, 3: 398-418.

Roberts, K. (1978) The Working Class, London: Longman.

--- (1997) 'Structure and agency: the new youth research agenda', in Bynner, J., Chisholm, L., and Furlong, A. (eds.) Youth, Citizenship and Social Change in a European Context, Aldershot: Ashgate.

Salo, H. (2003) 'Negotiating gender and personhood in the new South Africa', European Journal of Cultural Studies, 6, 3: 345-565.

Sibley, D. (1995) Geographies of Exclusion, London: Routledge.

Skeggs, B. (1997) Formations of Class and Gender, London: Sage. 
Social Exclusion Unit (1999) Bridging the Gap, London: Social Exclusion Unit.

Spano, A. (2002) 'Premodernity and postmodernity in Southern Italy', in Chamberlayne, P., Rustin, M., and Wengraf, T. (eds.) op. cit

Strathdee, R. (2001) "Change in social capital and "risk" in school to work transitions', Work, Employment and Society, 15, 2: 1-16.

Toynbee, P. (2003) Hard work, London: Bloomsbury.

Webster, C., Simpson, D., MacDonald, R., Abbas, A., Cieslik, M., Shildrick, T., and Simpson, M., (2004) Poor Transitions: Young Adults and Social Exclusion, Bristol. Policy Press.

White, M. and Forth, J. (1998) Pathways through Unemployment, York: JRF.

Wilson, W.J. (1996) When Work Disappears, New York: Knopf. 


\section{Biographical Information}

All the authors are part of the Youth Research Group, School of Social Sciences and Law, University of Teesside, Middlesbrough, TS1 3BA, UK. Any correspondence should go to the first named author (R.MacDonald@tees.ac.uk).

Robert MacDonald is Professor of Sociology. His research interests lie in the sociology of youth and of economic life. His publications include Youth, the 'Underclass' and Social Exclusion (as editor), Snakes and Ladders: Young People, Transitions and Social Exclusion and Poor Transitions (both as co-author). With Jane Marsh, he has recently published Disconnected Youth? Growing up in Poor Britain (Palgrave, 2005).

Dr. Tracy Shildrick is Senior Lecturer in Sociology and Youth Studies. Her doctorate explored the interrelationships between youth culture, youth transitions and illicit drug use. She has a long-standing interest in debates about young people and social class and has published several articles on these themes as well as co-authoring Poor Transitions (Policy Press, 2004). She is co-editor of the forthcoming book Drugs in Britain: Supply, Consumption and Control (Palgrave, 2006).

Dr. Colin Webster is Senior Lecturer in Criminology. He has researched and published in the areas of youth crime, racist violence, race and crime, drug treatment and community cohesion. As well as co-authoring Snakes and Ladders and Poor Transitions, he is the author of the forthcoming book ??????

Dr. Donald Simpson is a Research Fellow. He was the lead researcher on the Poor Transitions project as well as co-author and, for several years, has researched and published in the areas of educational policy and evaluation, the sociology of education and youth transitions. He is currently leading an action research project with the Tees Valley Connexions partnership. 


\section{End Notes}

${ }^{1}$ Andrea Abbas, Mark Cieslik and Mark Simpson also participated in the follow-up study and Jane Marsh co-researched the ESRC project (the initials JM appear in some interview extracts). We are indebted to them, to the Economic and Social Research Council (ESRC) and Joseph Rowntree Foundation (JRF) for their support, to all the research participants and to the editors of Sociology and the three anonymous reviewers for their very helpful comments. All real names of informants and their immediate neighbourhoods have been changed. In interview extracts, ... indicates a natural pause and ...//... indicates editing out of extraneous information, and material in square brackets is explanatory. Emphasis is as in the original, unless otherwise stated.

${ }^{2}$ As these authors point out, class analysis that relies on conventional, static, occupation-based schema is difficult to apply to social groups, like these we studied, who are undergoing transitions to the labour market, who are irregularly employed and whose biographies have shaped up in times of rapid economic restructuring.

${ }^{3}$ Two caveats: some young men were living away from Teesside as inmates of prisons or Young Offenders Institutes. Their home addresses remained in Willowdene or East Kelby. Secondly, our research design for the follow-up study possibly warded against finding those who had left Teesside. As noted earlier, we were however able to locate the whereabouts (i.e. in the same wards) of the majority of our original participants.

${ }^{4}$ There were other benefits of local crime. Whilst some resented these offers, others took pragmatic advantage of the availability of cheap, shoplifted goods or contraband cigarettes and alcohol imported from France, duty free.

${ }^{5}$ Based on interviews with professionals working in deprived neighbourhoods, Atkinson and Kintrea (2004) report similar findings to our own about local understandings of social exclusion, the role of socially and geographically restricted networks and area effects on life chances.

${ }^{6}$ A small minority did show greater awareness and pointed, as Zack did earlier, to the potential effects of growing up in a poor neighbourhood on their own biography.

${ }^{7}$ Historically, employment in Teesside has been highly gendered (Beynon et al, 1994). Its industrial heritage is one of relatively skilled, manual, male employment, predominantly in steel, chemicals and engineering. Women's employment has been less extensive, lower paid, lower skilled. As elsewhere, female employment and service sector work, for men and women, has increased over the past thirty years. Much of this - and the remaining factory-based production - is casualised, insecure and low paid (ibid.). In our studies, young women and men reported generally similar labour market experiences, albeit often in gender segregated jobs. For this reason we have not disaggregated our analysis here by gender (see MacDonald and Marsh, 2005).

${ }^{8}$ Many informants referred vaguely (and probably inaccurately) to 'redundancy' as the reason why they were no longer in a particular job. We also heard many instances of what seemed like unfair dismissal (e.g. for missing one day's work because of sickness), recounted with the weary tone of the 'taken for granted'. It was us, not them, that dwelt on these cases and offered terms like 'unfair dismissal' and 'exploitation' to describe them.

${ }^{9}$ One might wonder (to paraphrase one reviewer of this paper) which is most important - class or place - in explaining the youth transitions we uncovered? Our answer here stresses how class experiences are mediated through place. Obviously, contemporary forms of working-class culture reflect localised (i.e. regional down to neighbourhood) histories of class development. The transitions and biographical strategies of young working-class people in South London (Ball et al, 2000) share some similarities but have many differences with those described here (see MacDonald and Marsh, 2005). In depressed local labour markets in Scotland, the careers of working-class young men are near-identical to those of our interviewees (Furlong and Cartmel, 2004). We could also describe, if space allowed, the dramatically different school-to-work careers of young people from middle-class wards nearby to those we studied. 
For instance, in 1998, 83 per cent of 16 year-olds from affluent 'Ackthorpe' progressed into further education (and zero per cent became unemployed). In working-class 'Orchard Bank', three miles away, only 17 per cent continued in education and 30 per cent became unemployed.

${ }^{10}$ One of the authors (DS) is currently writing a critique of this term and the role of reflexivity in the making of youth transitions.

$\mathrm{rfm} /$ sociology paper - final - march $15^{\text {th } 2005}$ 